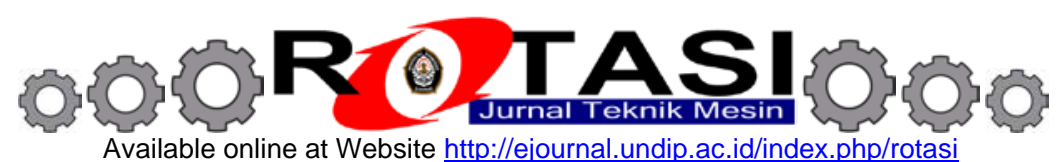

\title{
Pengukuran Distribusi Beban Telapak Kaki Manusia Saat Berdiri Tegak Menggunakan Sensor FSR 402
}

\author{
Dwi Basuki Wibowo \\ Departemen Teknik Mesin, Fakultas Teknik, Universitas Diponegoro \\ Jl. Prof. Sudharto, SH., Tembalang-Semarang 50275, Telp. +6224760059 \\ Email: ir.dwibasuki.ms@gmail.com
}

\begin{abstract}
Abstrak
Manusia saat berdiri tegak ke dua telapak kaki bagian tumit menanggung beban $60 \%$ dari berat tubuh. Saat berjalan dan tumit menghentak di landasan, beban satu kaki bisa mencapai 70\% dari berat tubuh. Beban yang besar di area tumit ini bisa menimbulkan nyeri hebat pada penderita calcanea spur (tumbuhnya taji di tulang tumit). Penelitian ini bertujuan mengetahui efektifitas penggunaan sensor FSR 402 buatan Interlink Electronics untuk mengukur distribusi beban di telapak kaki saat subyek berdiri tegak. Delapan sensor dipasang di sol sepatu dalam (shoe in-sole) disesuaikan dengan kecembungan kontur telapak kaki setiap subyek hasil pemindaian menggunakan 3D scanner. Hasil pengukuran menunjukkan beban rata-rata di area tumit pada tinggi hak sepatu $0 \mathrm{~cm}$ sebesar $27 \%$ dari berat tubuh atau lebih rendah $2 \%$ dibanding hasil penelitian sebelumnya. Menaikkan tinggi hak sepatu terbukti dapat menurunkan beban di area tumit dan menggesernya ke bagian tengah dan depan telapak kaki, juga sesuai dengan yang telah dilakukan oleh peneliti sebelumnya.
\end{abstract}

Kata kunci: beban telapak kaki, berdiri tegak, FSR 402

\section{Pendahuluan}

Telapak kaki manusia mengandung informasi sangat penting diantaranya untuk mengetahui tipe telapak kaki (flat foot, normal, atau high arch) [1], distribusi tekanan telapak kaki pasca operasi [2], menentukan ukuran sepatu [3], identifikasi pelaku tindak kejahatan dari jejak telapak kaki yang ditinggalkan [4], dan lain-lain. Distribusi beban di telapak kaki dipengaruhi oleh banyak faktor yaitu indeks massa tubuh (BMI: body mass index) [5], jenis kelamin [6], tipe telapak kaki atau luas kontak telapak kaki [7] dan aktifitas sehari-hari [8]. Saat manusia berdiri tegak, ke dua telapak kaki bagian belakang (rear foot/heel region) menanggung beban 60\% dari berat tubuh (Gambar 1a) [9]. Saat berjalan dan tumit menghentak di landasan (heel strike, Gambar 1b) beban satu kaki di area tumit bisa mencapai $70 \%$ dari berat tubuh [10].

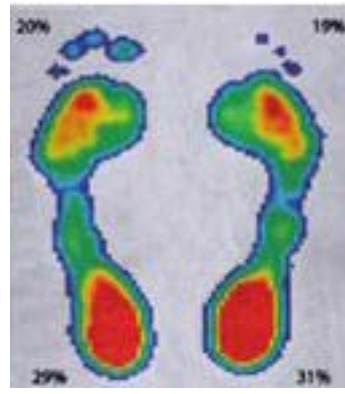

(a)

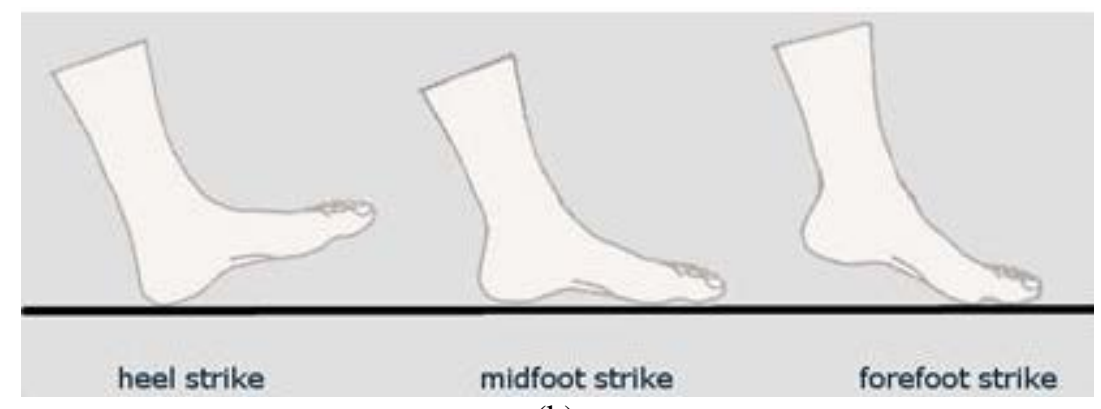

(b)

Gambar 1. Beban di telapak kaki saat berdiri dan berjalan.

Mengetahui distribusi beban telapak kaki saat berdiri tegak dapat dilakukan dengan cara mengukur kontur telapak kaki menggunakan 3D scanner for foot orthotic [11]. Cara lain yang lebih akurat adalah menggunakan force plate [12], contohnya diperlihatkan seperti pada Gambar 2 yang harganya berkisar \$30,000. Untuk menghemat biaya beberapa peneliti membuat sendiri alat tersebut seperti yang dilakukan oleh Periyasamy [6] dan Albon [13]. Albon memasang 10 sensor Force Sensing Resistor (FSR 402 produk Interlink Electronics [14]) pada stocking nilon untuk mengetahui perubahan distribusi beban di telapak kaki pada berbagai variasi ketinggian hak sepatu (Gambar 3).

FSR adalah suatu bahan polimer tipis yang tahanannya turun ketika dikenai beban pada permukaannya. FSR bukanlah loadcell atau strain gauge, meskipun memiliki sifat yang hampir sama. Pada penelitian ini sensor FSR yang digunakan sama dengan yang digunakan oleh Albon yaitu FSR 402 berdiameter 0.5 inch. (12.7 mm), tebal 0.018 inch. (0.46 mm), rentang sensitivitas gaya dan tekanan $100 \mathrm{~g} \mathrm{~s} / \mathrm{d} 10 \mathrm{~kg}$ dan $1.5 \mathrm{psi}$ s/d 150 psi. Perbedaan penelitian ini dengan yang dilakukan Albon adalah pada metode penentuan lokasi peletakan sensornya. 


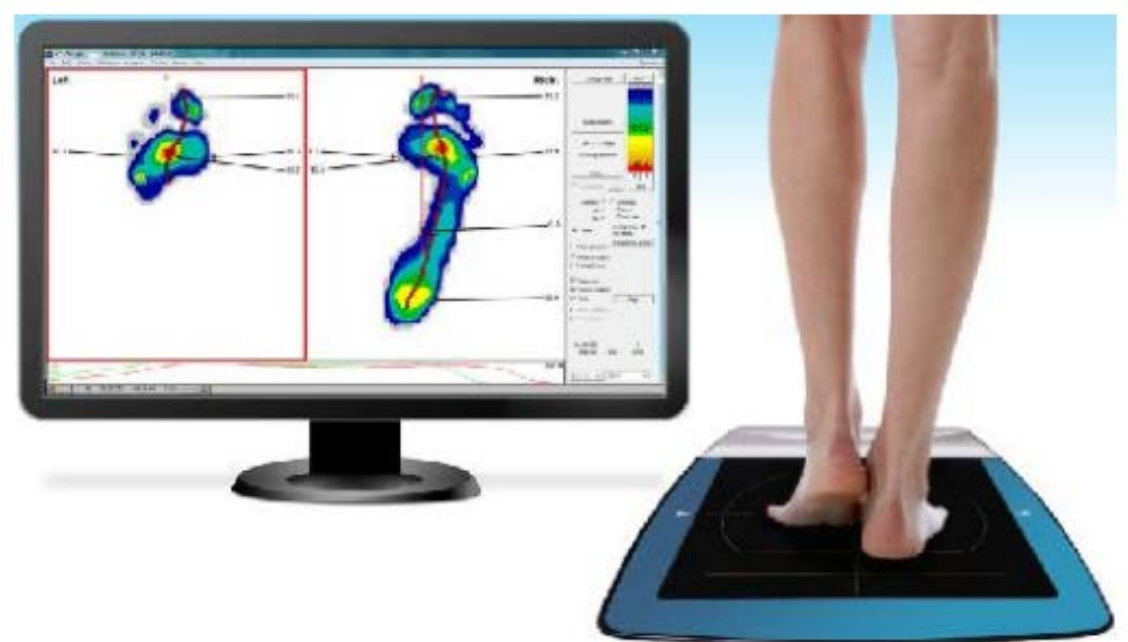

Gambar 2. Mengukur distribusi beban telapak kaki dengan Go-Tec Foot Mapping Sensor System
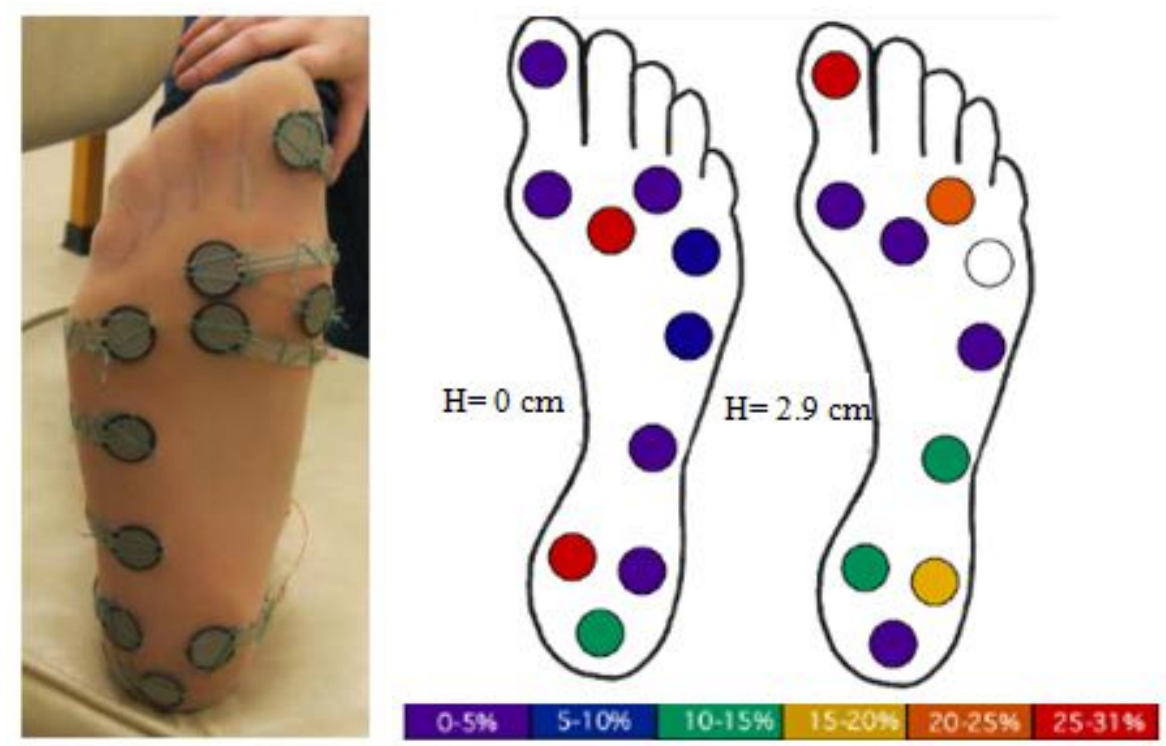

Gambar 3. Pola peletakan sensor FSR dan besarnya \% beban untuk tinggi hak sepatu $0 \mathrm{~cm}$ dan $2.9 \mathrm{~cm}$ pada penelitian Albon

Pola peletakan sensor dapat mengacu pada pembagian telapak kaki yang disarankan oleh para peneliti sebelumnya. Untuk jumlah sensor 6 buah dapat menggunakan pola pembagian seperti diperlihatkan pada Gambar 4(a) [15] dan 8 buah pada Gambar 4(b) [16], sedangkan untuk jumlah sensor 10 buah dapat menggunakan Gambar 5 [6, 17].

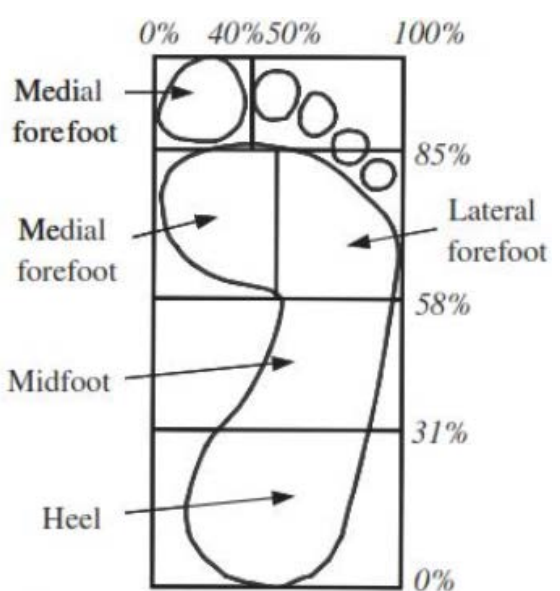

(a)

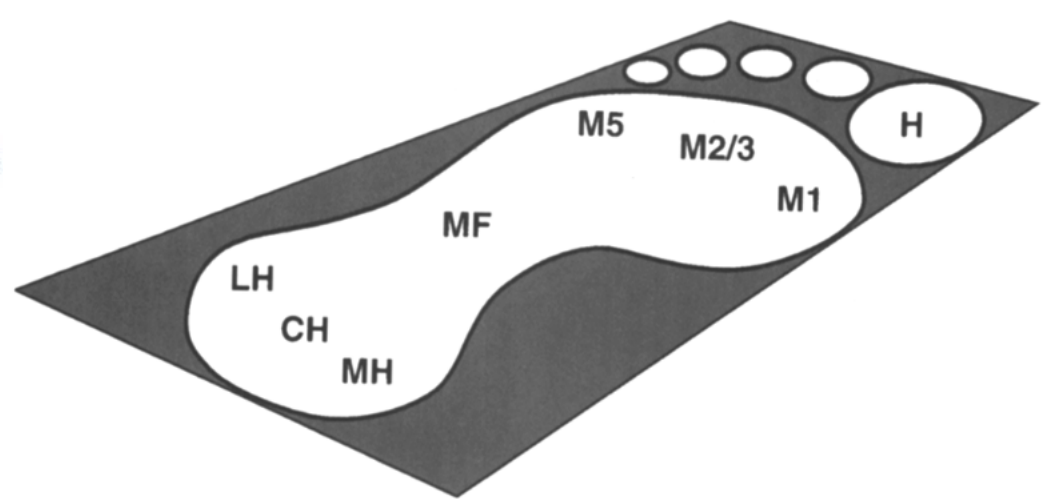

(b)

Gambar 4. Pembagian telapak kaki ke dalam 6 dan 8 area 


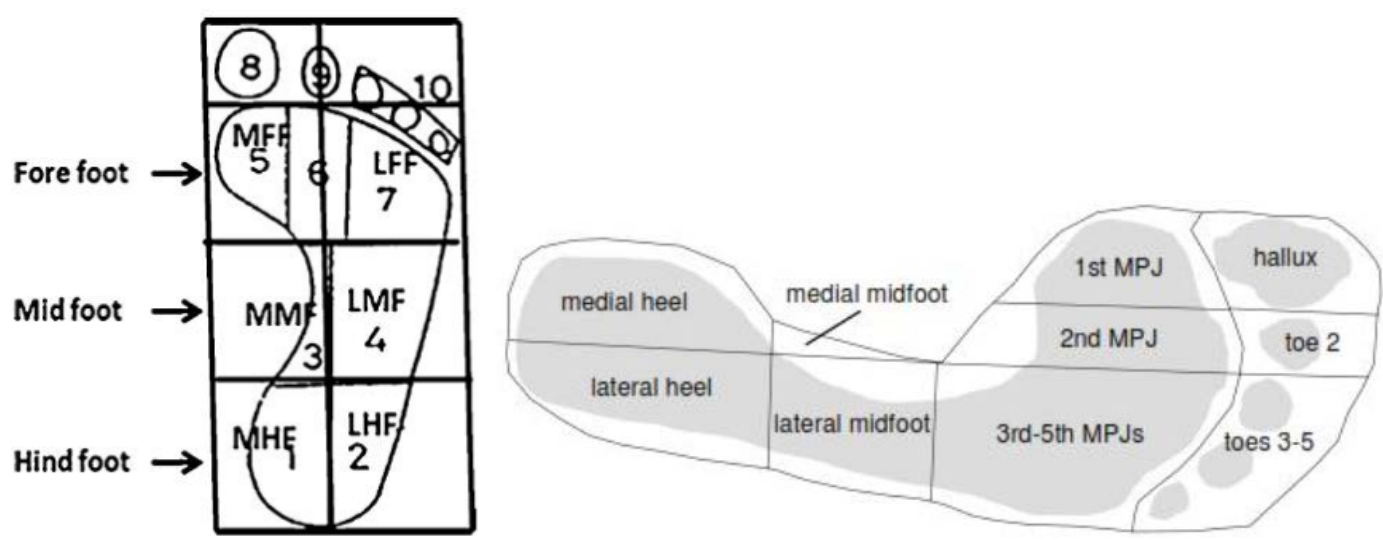

Gambar 5. Pembagian telapak kaki ke dalam 10 area

\section{Metode penelitian}

\subsection{Karakteristik Tegangan vs Beban Sensor FSR 402}

Sensor yang digunakan pada penelitian ini adalah FSR 402. Untuk mengetahui karakteristik perilaku respon sensor tersebut dibangun konstruksi seperti diperlihatkan pada Gambar 6. Pembebanan diberikan pada permukaan sensor hingga mencapai $\mathrm{L}=6000$ gram dengan peningkatan setiap 500 gram $(0.5 \mathrm{~kg})$. Dari hasil validasi diperoleh hubungan antara tegangan (V, Volt) dan beban (L, kg) yang dapat dinyatakan dalam bentuk persamaan polynomial derajat 3 (Persamaan 1 dan Gambar 7).
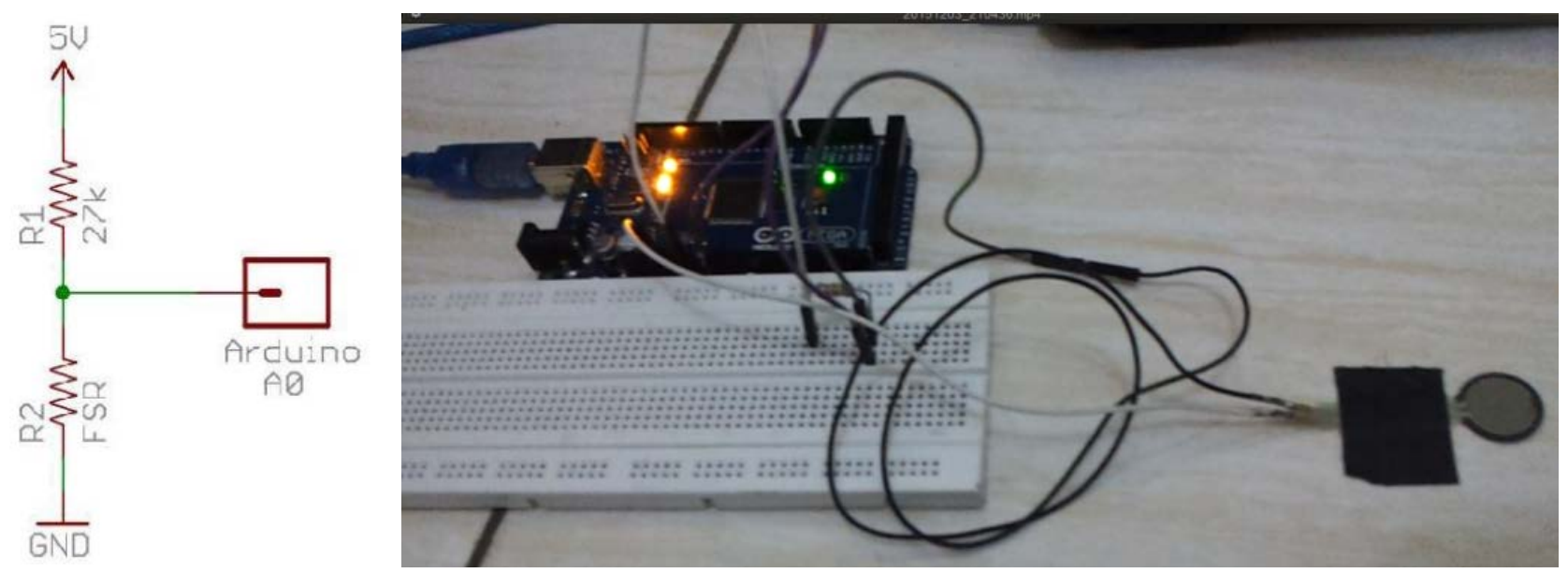

Gambar 6. Konstruksi FSR untuk mengetahui karakteristik perilaku respon sensor FSR 402

$L=927.78 V^{3}-1643.87 V^{2}+1083.49 V-31.02$

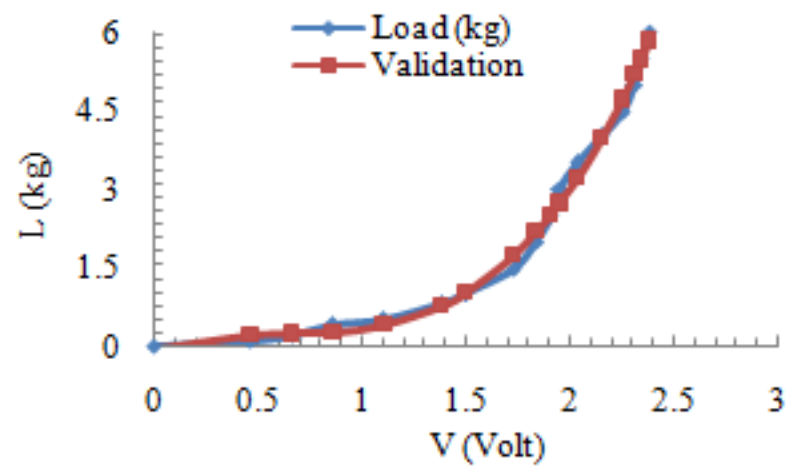

Gambar 7. Hubungan antara tegangan dan beban pada sensor FSR 402

\subsection{Karakteristik Subyek Penelitian}

Enam belas pasien dengan keluhan nyeri di telapak kaki (plantar fasciitis) dari Bagian Rekam Medik RSUD Tugurejo Semarang diseleksi oleh dokter spesialis orthopedic untuk menjadi subyek penelitian. Karakteristik subyek tersebut diperlihatkan pada Tabel 1. 
Tabel 1. Karakteristik subyek penelitian

\begin{tabular}{lcc}
\hline & Rentang Nilai & Rata-Rata dan Standard Deviasi \\
\hline Umur (tahun) & $27-73$ & $55 \pm 12$ \\
Jenis kelamin (laki-laki : perempuan) & $49-84.6$ & $3: 13$ \\
Berat badan (kg) & $144-172$ & $155 \pm 9.5$ \\
Tinggi badan (cm) & 145 \\
\hline
\end{tabular}

Setiap subyek diminta melakukan pemindaian telapak kaki menggunakan scanner 3D (Gambar 8, ScanPod3D buatan Vismach Technology China) [18] untuk menentukan lokasi peletakan sensor FSR. Setiap subyek juga diminta menggunakan sepatu uji dengan 4 variasi ketinggian hak sepatu $0 \mathrm{~cm}, 2 \mathrm{~cm}, 3 \mathrm{~cm}$ dan $4 \mathrm{~cm}$ yang masing-masing telah dipasang sensor-sensor di sol sepatu dalam (shoe in-sole) seperti diilustrasikan pada Gambar 9c.

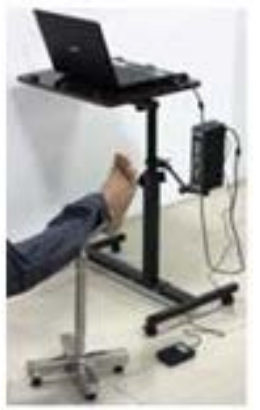

(a)
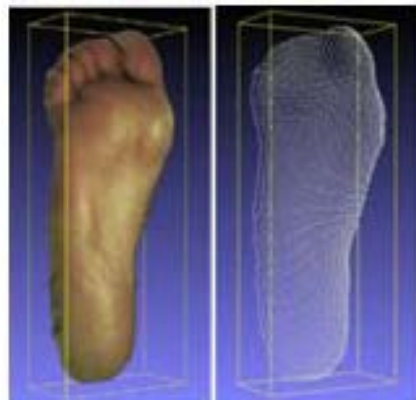

(b)

Gambar 8. Pemindaian telapak kaki tak berbeban, (a) Pemindaian 3D telapak kaki, (b) hasil pemindaian

\subsection{Pola Peletakan Sensor FSR di Telapak Kaki}

Pada penelitian ini digunakan 8 sensor FSR 402 yang dipasang di sol sepatu dalam (shoe in-sole) dengan isolasi dobel (double tape). Setiap sensor dihubungkan dengan 1 resistor. Luaran tegangan sensor FSR dibaca oleh microcontroller Arduino MEGA 2560 menggunakan input pin analog 10 bits. Selanjutnya tegangan tersebut dikirim ke software data akuisisi LabVIEW melalui serial USB untuk dikonversikan menjadi beban menggunakan persamaan 1.

Pola peletakan 8 sensor mengacu pada kontur telapak kaki hasil pemindaian menggunakan 3D scanner (Gambar 8a), yaitu pada area di telapak kaki yang deformasinya besar saat pasien berdiri tegak di atas landasan rata yang ekivalen dengan kontur kecembungan yang besar (Gambar 8b). Proses pemindaian dilakukan setelah telapak kaki subyek benar-benar lurus dan tidak miring ke kanan atau ke kiri yang dipandu oleh operator.

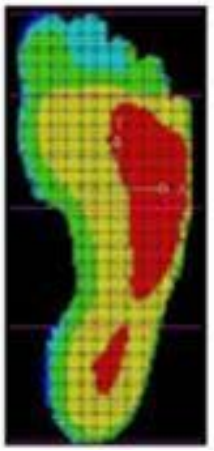

(a)

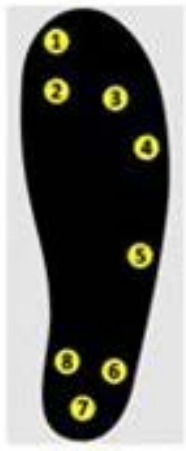

(b)

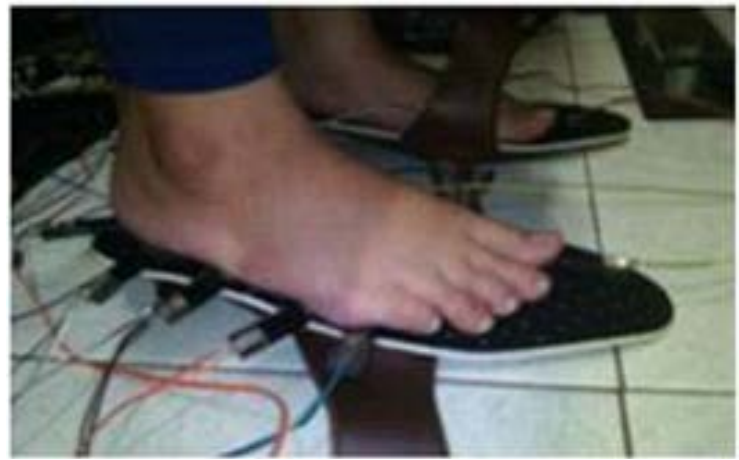

(d)

Gambar 9. Penentuan pola peletakan 8 sensor FSR di shoe in-sole, (a) plot distribusi nilai z dalam warna-warna yang berbeda, (b) pola peletakan 8 sensor dan (c) pengukuran distribusi beban pada telapak kaki akibat berat sendiri

Agar dapat menetapkan lokasi peletakan setiap sensor harus diketahui koordinat x, y, z kontur telapak kaki [11]. Caranya sebagai berikut: (1) import file .dxf hasil scanner 3D ke dalam software AutoCAD, (2) konversikan file tersebut menjadi solid model dan bandingkan dengan hasil dari scanner 3D, (3) buka Microsoft Excel dan import koordinat AutoCAD tersebut dengan cara mem-block obyek yang ingin diketahui koordinatnya, (4) lacak data-data koordinat $\mathrm{z}$ dari ujung tumit (heel cup) hingga ujung jari kaki yang terjauh dan menggradasinya dari nilai koordintat $\mathrm{z}$ terkecil hingga terbesar, (5) plot distribusi nilai z tersebut dalam warna-warna yang berbeda (merah terbesar dan biru gelap terkecil) seperti diperlihatkan pada Gambar 9a.

Gambar 9(b) memperlihatkan pola peletakan 8 sensor tersebut yaitu di: T1, hallux (sensor 1); M1, metatarsal 1 (sensor 2); M2, metatarsal 2 (sensor 3); M3, metatarsal 3 (sensor 4); MF, midfoot/arch (sensor 5); LH, lateral heel 
(sensor 6); $\mathrm{CH}$, center of heel (sensor 7); dan $\mathrm{MH}$, medial heel (sensor 8). Sedangkan Gambar 9c memperlihatkan pengukuran distribusi beban pada telapak kaki akibat berat sendiri. Proses pengukuran dilakukan setelah subyek benarbenar berdiri tegak yang diketahui (oleh operator) dari perbedaan nilai beban di setiap sensor antara kaki kanan dan kiri tidak lebih dari $2 \%$ [19].

\section{Hasil penelitian dan diskusi}

Tabel 2 memperlihatkan prosentase beban/setengah berat badan rata-rata di setiap area telapak kaki kanan pasien pada berbagai variasi ketinggian hak sepatu saat pasien berdiri tegak. Bila tinggi hak sepatu dinaikkan, sebagian gaya berpindah ke area telapak kaki bagian tengah (MF: midfoot atau arch of the foot). Pada area MF ini beban puncak naik lebih tinggi secara signifikan dari 1.06\% menjadi 10.01\% pada tinggi hak sepatu $2 \mathrm{~cm}, 10.68 \%$ pada tinggi hak sepatu 3 $\mathrm{cm}$, dan $11.43 \%$ pada tinggi hak sepatu $4 \mathrm{~cm}$ dibandingkan dengan tinggi hak sepatu $0 \mathrm{~cm}$. Prosentase beban terbesar terjadi di jempol kaki (T1: hallux). Di area ini peningkatan beban puncak terbesar terjadi pada tinggi hak sepatu $4 \mathrm{~cm}$ yaitu 15.74\%. Hasil ini sesuai dengan penelitian Albon yang menunjukkan saat tinggi hak sepatu dinaikkan menjadi 2.9 cm beban di MF naik dari 5\% menjadi 12\% dan di T1 dari 5\% naik menjadi 17\% dibandingkan dengan tinggi hak sepatu $0 \mathrm{~cm}$ [13]. Albon memvariasikan 6 macam tinggi hak sepatu yaitu $0 \mathrm{~cm}, 0.9 \mathrm{~cm}, 2.9 \mathrm{~cm}, 7.6 \mathrm{~cm}, 8.1 \mathrm{~cm}$, dan 9.8 $\mathrm{cm}$. Karakteristik pembebanan pada tinggi hak sepatu di atas $2.9 \mathrm{~cm}$ sangat berbeda dengan tinggi hak sepatu $4 \mathrm{~cm}$ sehingga tidak dapat dilakukan perbandingan.

Tabel 2. Beban/setengah berat badan (\%) rata-rata di setiap area telapak kaki

\begin{tabular}{|c|c|c|c|c|}
\hline \multirow{2}{*}{$\begin{array}{c}\text { Area } \\
\text { (Sensor) }\end{array}$} & \multicolumn{4}{|c|}{ Beban/berat badan (\%) } \\
\hline & Tinggi hak sepatu $0 \mathrm{~cm}$ & Tinggi hak sepatu $2 \mathrm{~cm}$ & Tinggi hak sepatu $3 \mathrm{~cm}$ & Tinggi hak sepatu $4 \mathrm{~cm}$ \\
\hline $\mathrm{T} 1(1)$ & $1.02 \pm 0.14$ & $11.47 \pm 0.23$ & $13.19 \pm 0.13$ & $15.74 \pm 0.14$ \\
\hline M1 (2) & $1.05 \pm 0.13$ & $1.11 \pm 0.09$ & $0.97 \pm 0.02$ & $1.53 \pm 0.02$ \\
\hline M2 (3) & $0.95 \pm 0.03$ & $7.39 \pm 0.59$ & $9.45 \pm 0.44$ & $8.45 \pm 0.32$ \\
\hline M3 (4) & $2.45 \pm 0.02$ & $6.10 \pm 0.55$ & $0.77 \pm 0.04$ & $0.87 \pm 0.01$ \\
\hline MF (5) & $1.06 \pm 0.12$ & $10.01 \pm 0.42$ & $10.68 \pm 0.51$ & $11.43 \pm 0.83$ \\
\hline LH (6) & $1.23 \pm 0.04$ & $8.66 \pm 0.17$ & $6.87 \pm 0.22$ & $10.13 \pm 0.42$ \\
\hline $\mathrm{CH}(7)$ & $14.32 \pm 0.21$ & $1.36 \pm 0.11$ & $0.91 \pm 0.04$ & $0.89 \pm 0.01$ \\
\hline $\mathrm{MH}(8)$ & $11.45 \pm 0.92$ & $11.55 \pm 0.47$ & $9.84 \pm 0.17$ & $13.79 \pm 0.07$ \\
\hline
\end{tabular}

Keterangan: nilai dinyatakan dalam bentuk rata-rata \pm standard deviasi

Pada area bagian dalam telapak kaki depan (M1: medial forefoot/metatarsal 1) beban puncak terlihat kecil dibandingkan area-area lain pada semua ketinggian hak sepatu. Pada area bagian tengah telapak kaki depan (M2: metatarsal 2) nilai beban puncaknya semakin naik dengan semakin tingginya hak sepatu dimana pada ketinggian hak sepatu $3 \mathrm{~cm}$ terlihat adanya peningkatan beban signifikan dari 0.95\% menjadi 9.45\% dibandingkan dengan tinggi hak sepatu $0 \mathrm{~cm}$. Di area bagian luar telapak kaki depan (M3: lateral forefoot/metatarsal 3) beban terbesar terjadi pada ketinggian hak sepatu $2 \mathrm{~cm}$ tetapi turun secara signifikan pada tinggi hak sepatu $3 \mathrm{~cm}$ dan $4 \mathrm{~cm}$. Hasil ini sesuai dengan penelitian Shimizu et al [20] dan Xiaohong et al [21] yang membuktikan menggunakan sepatu hak tinggi dapat menggeser beban telapak kaki ke metatarsal head M2 serta menggeser beban dari M3 ke M2. Penelitian Albon juga menunjukkan hasil yang identik saat tinggi hak sepatu dinaikkan menjadi $2.9 \mathrm{~cm}$ yaitu beban di M2 naik dari $6 \%$ menjadi 27\% sementara di M3 turun mendekati 0\% dibandingkan dengan tinggi hak sepatu $0 \mathrm{~cm}$ [13].

Ketika tinggi hak sepatu dinaikkan sebagian gaya juga berpindah ke area bagian dalam telapak kaki belakang (MH: medial heel) dibandingkan dengan area bagian luar (LH: lateral heel) dan area bagian tengah telapak kaki belakang (CH: center of heel), seperti terlihat pada Gambar 10. Di area MH nilai beban puncak terlihat besar pada semua ketinggian hak sepatu. Di area LH beban puncak yang tinggi terjadi pada ketinggian hak sepatu $2 \mathrm{~cm}, 3 \mathrm{~cm}$, dan $4 \mathrm{~cm}$ dimana peningkatan beban puncak terbesar terjadi pada ketinggian hak sepatu $4 \mathrm{~cm}$ dibandingkan tinggi hak sepatu $0 \mathrm{~cm}$. Prosentase beban terbesar terjadi di area $\mathrm{CH}$ pada tinggi hak sepatu $0 \mathrm{~cm}$, tetapi nilai beban puncaknya turun secara signifikan dari $14.32 \%$ menjadi $1.36 \%$ pada tinggi hak sepatu $2 \mathrm{~cm}$; $0.91 \%$ pada tinggi hak sepatu $3 \mathrm{~cm}$; dan $0.89 \%$ pada tinggi hak sepatu $4 \mathrm{~cm}$ (Tabel 2). Hasil ini sesuai dengan penelitian Albon yang menunjukkan saat tinggi hak sepatu dinaikkan menjadi $2.9 \mathrm{~cm}$ beban di CH turun dari 10\% menjadi 5\% , di MH turun dari 25\% menjadi 10\%, dan di LH naik dari 5\% menjadi 15\% dibandingkan dengan tinggi hak sepatu 0 cm [13].

Di area CH hasil pengukuran tersebut identik dengan analisis Metode Elemen Hingga (MEH) penelitian Wibowo et al yang menunjukkan tekanan rata-rata di $\mathrm{CH} 162,296.87 \mathrm{~N} / \mathrm{m}^{2}$ pada tinggi hak sepatu $0 \mathrm{~cm}$ dan ketika tinggi hak sepatu dinaikkan tekanan rata-ratanya turun sebesar 75.8\% pada tinggi hak sepatu $2 \mathrm{~cm}$, 78.6\% pada tinggi hak sepatu 3 $\mathrm{cm}$, dan $81.8 \%$ pada tinggi hak sepatu $4 \mathrm{~cm}$ [22]. Nilai tekanan rata-rata hasil penelitian Wibowo et al ini berbeda sekitar 12.20\%, 15.82\%, 37.16\% dan 24.47\% masing-masing pada tinggi hak sepatu $0 \mathrm{~cm}, 2 \mathrm{~cm}, 3 \mathrm{~cm}$ and $4 \mathrm{~cm}$ dibandingkan dengan tekanan rata-rata di $\mathrm{CH}$ yang diperoleh dari hasil pengukuran. Pada penelitian Wibowo et al lokasi CH ditentukan secara pasti yaitu di garis sumbu tumit (heel center line) pada jarak 0.15 panjang telapak kaki (FL: foot length) diukur dari ujung tumit [5]. Sedangkan pada penelitian ini lokasi CH, MH dan LH ditentukan sembarang asalkan masih di area tumit dan berwarna merah (Gambar 9a). Perbedaan lokasi CH tersebut menyebabkan perbedaan 
signifikan antara hasil pengukuran yang dilakukan pada penelitian ini dengan analisis MEH yang dilakukan oleh Wibowo et al [22].

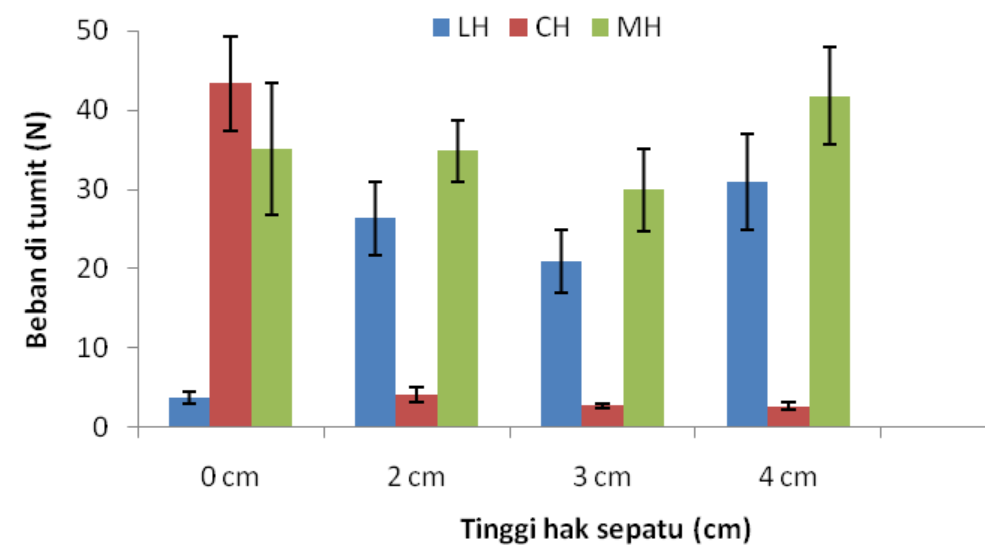

Gambar 10. Distribusi beban di area tumit pada tinggi hak sepatu $0 \mathrm{~cm}, 2 \mathrm{~cm}, 3 \mathrm{~cm}$, dan $4 \mathrm{~cm}$

Jumlah prosentase beban/setengah berat badan rata-rata di area tumit (sensor 6, 7, dan 8) pada tinggi hak sepatu $0 \mathrm{~cm}$ adalah $27 \%$ atau lebih rendah $2 \%$ dibanding hasil penelitian sebelumnya (Gambar 1a) [9]. Hal ini disebabkan kurangnya jumlah sensor FSR yang dipasang di area tersebut.

\section{Kesimpulan}

Sensor FSR 402 dapat digunakan untuk mengukur distribusi beban telapak kaki manusia yang berkontak dengan landasan. Akan tetapi karena diameter nominal sensor $12.7 \mathrm{~mm}$ yang relatif besar menyebabkan jumlah sensor yang dipasang tidak bisa banyak (maksimal 15 sensor). Solusinya menggunakan sensor FSR 400 buatan Interlink yang berdiameter $5.0 \mathrm{~mm}$. Disamping itu tebal sensor yang relatif tipis (0.46 mm untuk FSR 402 dan $0.30 \mathrm{~mm}$ untuk FSR 400) tidak bisa menumpu sempurna di setiap titik pengukuran yang menyebabkan data terukur lebih kecil dibandingkan menggunakan force plate. Solusinya mengganjal bagian bawah sensor dengan karet tebal 2-3 mm berdiameter sedikit lebih besar dari diameter sensor. Hasil pengukuran menunjukkan menaikkan tinggi hak sepatu dapat menggeser beban ke bagian tengah dan depan telapak kaki. Beban di area tumit turun dengan semakin naiknya tinggi hak sepatu yang sangat berguna untuk mengurangi nyeri di area tumit bagi penderita adanya taji di tulang tumit (calcanea spur).

\section{Referensi}

1. Wunderlich, R.E., Cavnagh, P.R., 2001, Gender differences in adult foot shape: Implications for shoe design. Med. Sci. Sports Exer., Vol. 33, pp. 605-611.

2. Sabut, S.K., Kumar, R., Mahadevappa, M., 2010, Design of an insole embedded foot pressure sensor controlled FES system for foot drop in stroke patients. Proceedings of 2010 International Conference on System in Medicine and Biology 16-18 December 2010. IIT Kharagpur India.

3. DeMars, R., Hamilton, J., Lee, B., et al., 2008, Development of a Parametric Design for a Shoe Insole Insert. Final Report Fundamentals of CAD ME 6104. The AMEDD Center and School. May 2.

4. Angga Pramuditia V., Wibowo, D.B., 2017, Estimasi berat dan tinggi badan orang Jawa dari pengukuran telapak kaki. Jurnal Teknik Mesin S-1, Vol. 5, No. 1.

5. Rodrigo, A.S., Goonetilleke, R.S., Xiong, S., 2013, Load distribution to minimize pressure-related pain on foot: a model. Ergonomics, 56:7, 1180-1193, DOI: 10.1080/00140139.2013.797111.

6. Periyasamy, R., Mishra, A., Anand, S., et al., 2011, Preliminary investigation of foot pressure distribution variation in men and women adults while standing. The Foot Vol. 21, pp. 142-148.

7. Chuckpaiwong, B., Nunley, J.A., Mall, N.A., et al., 2008, The effect of foot type on in-shoe plantar pressure during walking and running. Gait \& Posture Vol. 28, pp. 405 - 411, Elsevier.

8. Rodgers, M.M., 1988, Dynamic biomechanics of the normal foot and ankle during walking and running. Physical Therapy Vol. 68, No. 12, pp. 1822-1830.

9. Chia, J.K.K., Suresh, S., Kuah, A., Ong, J.L.J., et al., 2009, Comparative trial of the foot pressure patterns between corrective orthotics, formthotics, bone spur pads and flat insoles in patients with chronic plantar fasciitis. Ann Acad Med Singapore Vol. 38, pp. 869-75.

10. Giddings, V.L., Beaupre, G.S., Whalen, R.T., Carter, D.R., 2000, Calcaneal Loading During Walking and Running. Medicine \& Science in Sport \& Exercise, Journal of The American College of Sports Medicine.

11. Wibowo, D.B. Haryadi, G.D., Suprihanto, A., 2016, Estimation of Foot Pressure from Human Footprint Depths Using 3D Scanner. AIP Conference Proceedings, ISBN: 978-0-7354-1365-8, Vol. 1717, doi: 10.1063/1.4943451.

12. Rod, C., 1999, Standing, walking, running, and jumping on a force plate. Am. J. Phys, 67 (4). 
13. Theresa, A., 2011, Plantar Force Distribution for Increasing Heel Height Within Women's Shoes. Physics Department, The College of Wooster, Wooster, Ohio 44691, USA.

14. Interlink Electronics. FSR Force Sensing Resistor - Integration Guide and Evaluation Parts Catalog. 400 Series Evaluation Parts with Suggested Electrical Interfaces, 546 Flynn Road, Camarillo, CA 93012.

15. Lee, Y.H., et al., 2005, Effects of shoe inserts and heel height on foot pressure, impact force, and perceived comfort during walking. Applied Ergonomics Vol. 36, pp. 335-362, Elsevier.

16. Rosenbaum, D., Becker H.P., 1997, Plantar pressure distribution measurements: technical background and clinical applications, J Foot Ankle Surg 3 1-14.

17. Amanda, T.J., et al., 2004, Effects of experimentally induced plantar insensitivity on forces and pressure under the foot during normal walking. Gait and Posture Vol. 20, pp. 232-237, Elsevier.

18. ScanPod3D, 2013. 3D Scanner Mini and Scansoft for Foot Orthotic. Vismach Technology Ltd., www.scanpod3d.com.

19. Robinette, K.M., Daanen, H.A.M., 2006, Precision of the CAESAR scan-extracted measurements. Appl Ergon, Vol.37, No.3, pp.259-265.

20. Mika, S., Andrew, P.D., 1999, Effect of heel height on the foot in unilateral standing. J. Phys. Ther. Sci. 11: 95-100.

21. Jia, X., Wang, R., Winson, L., 2009. Effects of shoe heel height on loading and muscle activity for trans-tibial amputees during standing. Tsinghua Science and Technology. ISSN 1007-0214 01/18 pp 281-286, Volume 14, Number 3.

22. Wibowo, D.B., Widodo, A., Haryadi, G.D., et al., 2017, Effects of Different Heel Heights on Heel Pressure Distribution for Calcaneal Spur Patients During Standing: Finite Element Analysis. $2^{\text {nd }}$ International Joint Conference on Advance Engineering and Technology (IJCAET) 2017. Sanur Bali, 24-26 August 2017 